\title{
Survey of Indigenous Species of Marine Algae in Korea: New Record of Hypnea chordacea Kützing (Gigartinales, Rhodophyta)
}

\author{
Pil Joon $\mathrm{KANG} \cdot \mathrm{Ki}$ Wan $\mathrm{NAM}^{\dagger}$ \\ (Pukyong National University)

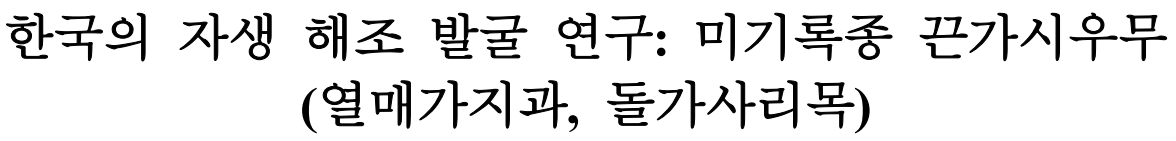 \\ 강필준 · 남기완 \\ (부경대학교)
}

\begin{abstract}
In the course of the survey of indigenous species, a red algal Hypnea species was collected from eastern coast of Korea. This species is distinct from other species of Hypnea in having percurrent and cylindrical axis, linear to lanceolate branchlets in axes except their lower portion and medullary cell walls without lenticular thickenings. This Korean entity is identified as Hypnea chordacea Kützing (Gigartinales, Rhodophyta) based on those features. This is the first record of Hypnea chordacea in Korea.
\end{abstract}

Key words: First record, Hypnea chordacea, Morphology, Taxonomy, Korea

\section{I . Introduction}

Since Kang (1966), many species have been newly recorded in the Korean marine algal floristic list (Kang, 1968; Lee and Kang, 1986, 2002; Lee, 2008; Kim et al., 2013). Recently, this kind of study has been vigorously carried out in Korea (Jeong et al., 2013; Kang and Nam, 2013, 2014). It appears that about 900 species are currently reported in the Korean marine algal flora (Boo and Ko, 2012; Kim et al., 2013).

Several marine algal species were discovered in
Korea during the survey of indigenous species. Of these, one red algal species, Hypnea chordacea Kützing (Gigartinales, Rhodophyta) which was collected from east coast of Korea, was observed in details. Morphological and taxonomic data on this species are given in the present study. This is the first record of Hypnea chordacea in Korea.

\section{II . Materials and Methods}

Specimens for the present study were collected along the east coast of Korea. Taxonomic data

† Corresponding author : 051-629-5922, kwnam@pknu.ac.kr

* This work was supported by a grant from the National Institute of Biological Resources (NIBR), funded by the Ministry of Environment (MOE) of the Republic of Korea and by a grant from Marine Biotechnology Program and National Life Collection program(MABIK 2014-001-05) funded by the Ministry of Oceans and Fisheries, Korea 


\section{Survey of Indigenous Species of Marine Algae in Korea: New Record of Hypnea chordacea Kützing (Gigartinales, Rhodophyta)}

were obtained from fresh, liquid-preserved and herbarium specimens. Liquid-preserved material was stored in a $10 \%$ solution of Formalin/seawater. For anatomical observations the material was cleared in $5-10 \% \mathrm{NaOH}$ in distilled water for 2-7 days, and then rinsed in distilled water. Blades dissected from the cleared materials were hand sectioned, transferred to a slide with a drop of distilled water, and mounted in pure glycerin. In some instances, a smearing method for microscopic examination was employed. Measurements are given as width and length. For photographs the sections were stained with $0.5-1.0 \%$ aqueous methylene blue, aniline blue or hematoxylin. For permanent slides, the glycerin was exchanged with $10-20 \%$ corn syrup.

\section{Results and Discussion}

\section{Hypnea chordacea Kützing 1847: 776.}

Korean name: Kkeun-ga-si-u-mu nom. nov. (신칭: 끈가시우무).

Specimens examined: PKNU 0000187710, PKNU 0000187713 (Uljin: 13.viii.2013).

Habitat: Growing on rock near upper to lower intertidal.

Morphology: Thalli up to 5-20 $\mathrm{cm}$ high [Fig. 1A], terete, dark red to brown in color, cartilaginous in texture; main axes percurrent, cylindrical, issuing branches and proliferations; branches bearing branchlets in alternate to spiral manner [Fig. 1B]; branchlets linear to lanceolate, rare or naked below middle portion of axes, with distinct apical cell [Fig. 2A], 1-5 mm long; lenticular thickenings absent in the wall of medullary cells; cortex two to four cell layer thick [Fig. 2B]; medullary cells round to elliptical in transverse section [Fig. 2C], linear to cylindrical shape in longitudinal section, with many pit connection between adjacent cells [Fig. 2D]. Sexual and tetrasporangial plants were not collected during this study.

Remarks: Hypnea chordacea Kützing, which was originally described from Indonesia (Silva et al., 1996), is distributed in eastern Asia including Japan, China and Taiwan (Guiry and Guiry, 2015). In general, proliferations and medullary lenticular thickenings have been used as character with taxonomic value in Hypnea (Tseng, 1984; Chiang, 1997; Masuda et al., 1997; Xia and Wang, 1997; Geraldino et al., 2010). Proliferations in our specimens were rare or naked below middle portion of axes as described in the previous study (Xia and Wang, 1997). The medullary thickenings were also not observed as in other reports (Xia and Wang, 1997). These Korean specimens are identified as Hypnea chordacea based on those features. Hypnea chordacea is distinct from other Korean species of Hypnea in having percurrent and cylindrical axis, linear to lanceolate branchlets in axes except their lower portion and medullary cell walls without lenticular thickenings. This species is newly recorded in Korea, here. 

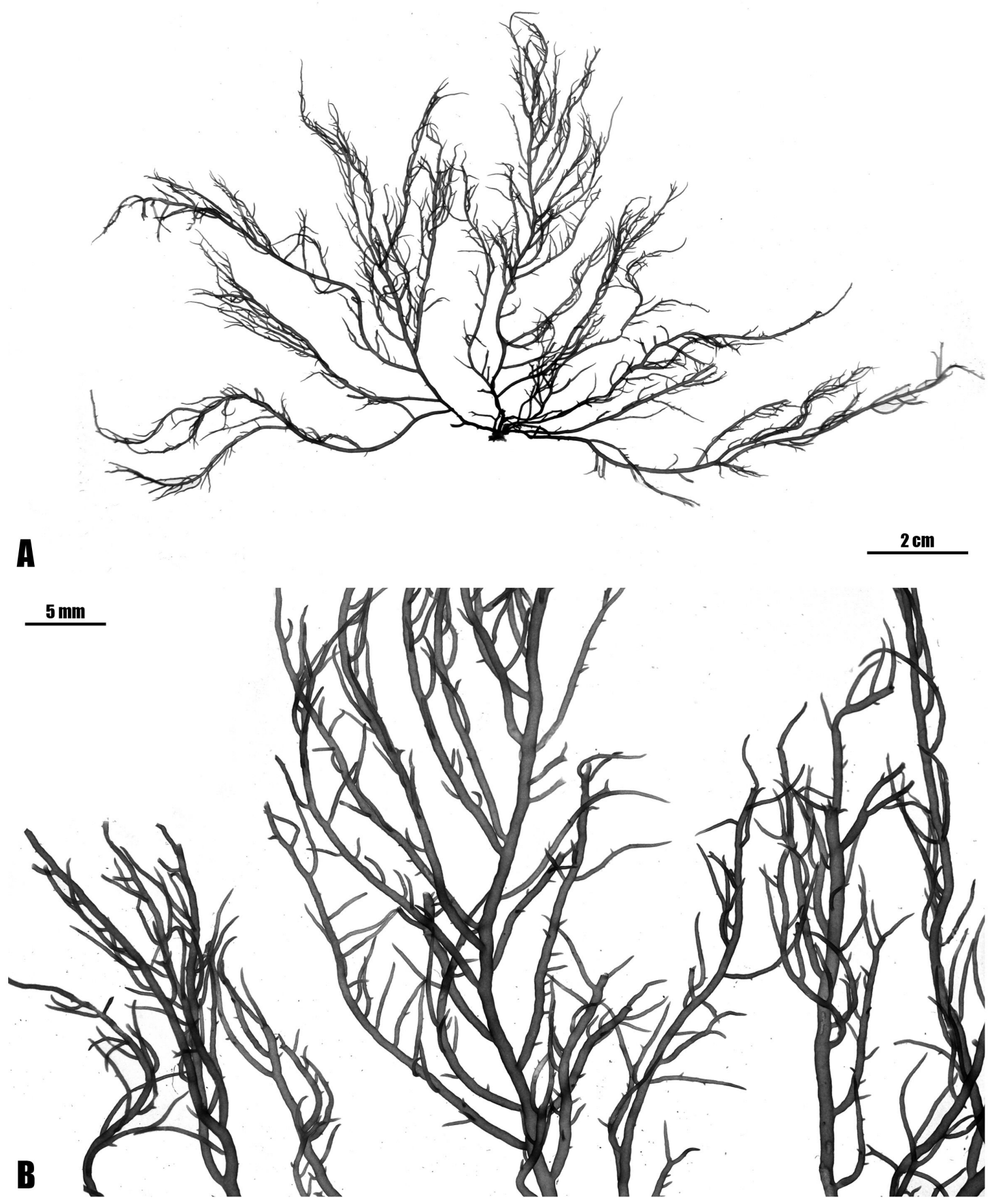

[Fig. 1] Hypnea chordacea. A, Habit of vegetative plant; B, Details of vegetative branches covered densely with many branchlets 

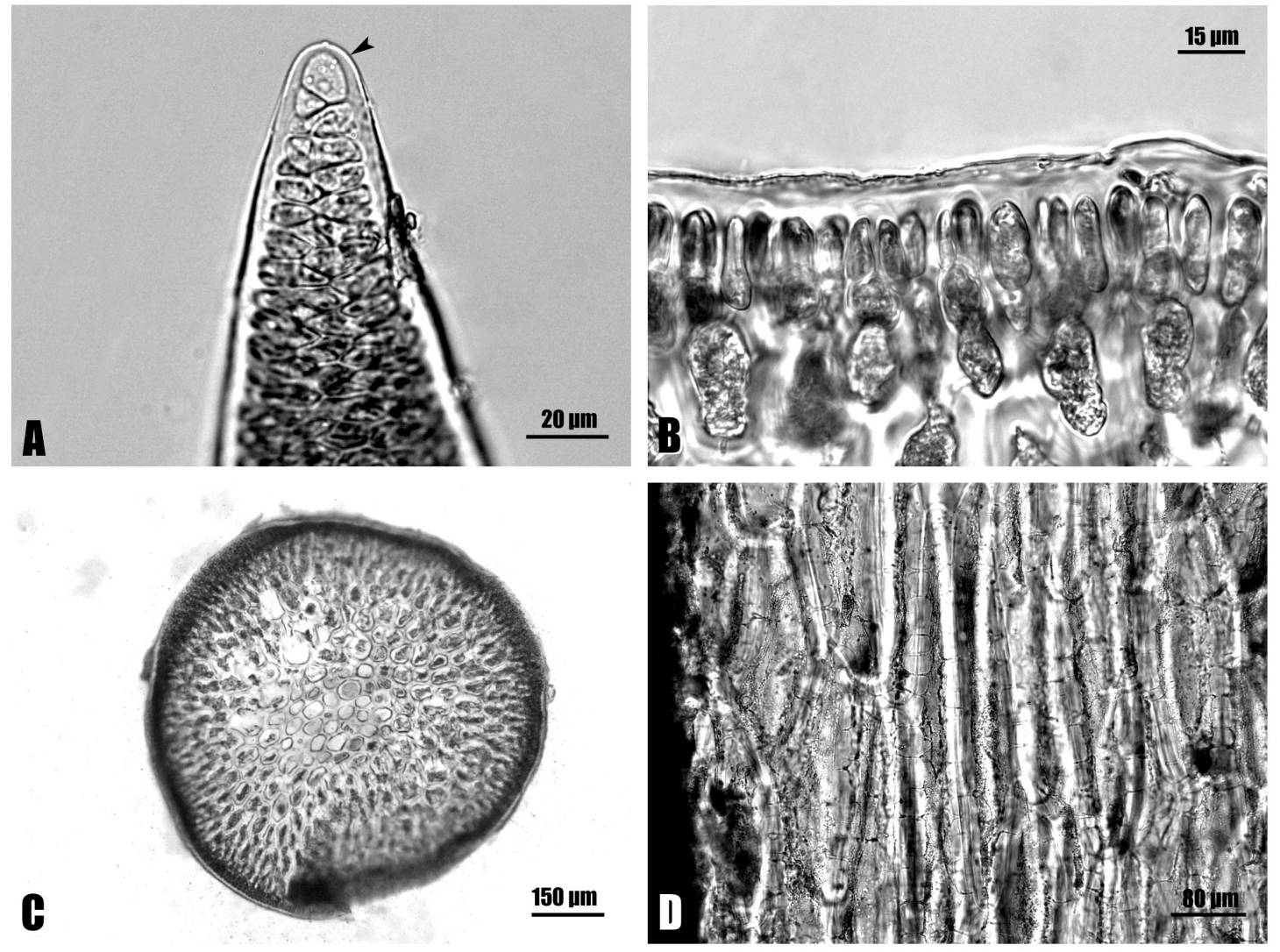

[Fig. 2] Hypnea chordacea. A, Distinct apical cell (arrowhead) at apex of branchlet; B, Cortical cell layer; C, Transverse section of branch; D, Cylindrical medullary cell with many pit connections between adjacent cells in longitudinal section of branch

\section{References}

Boo, S. M. \& Ko, Y. D.(2012). Marine Plants from Korea. Seoul: Marine \& Extreme Genome Research Centre Program.

Chiang, Y. -M.(1997). Species of Hypnea Lamouroux (Gigartinales, Rhodophyta) from Taiwan. In: Taxonomy of Economic Seaweeds. (Abbott, I.A. Ed) Vol. 6, La Jolla, California: California Sea Grant College System, 163 177.

Geraldino, P. J. L. Riosmena-Rodriguez, R. - Liao, L. M. \& Boo, S. M.(2010). Phylogenetic relationships within the genus Hypnea (Gigartinales, Rhodophyta), with a description of $H$. caespitosa sp. nov. Journal of Phycology 46, 336 345.
Guiry, M. D. \& Guiry, G. M.(2015). AlgaeBase. World-wide electronic publication, National University of Ireland, Galway.

http://www.algaebase.org; searched on 16 January October 2015.

Jeong, S. Y. • Won, B. Y. • Kang, P. J. • Kang, J. C. - Kim, M. S. • Nam, K. W. \& Cho, T. O.(2013). New record of some red algal species (Rhodophyta) from Korea. Journal of Ecology and Environment 36, 439 448.

Kang, J. W.(1966). On the geographical distribution of marine algae in Korea. Bulletin of Pusan Fisheries College 7, 1 125.

Kang, J. W.(1968). Illustrated Encyclopedia of Fauna and Flora of Korea, Vol.8. Marine Algae. Seoul: Samhwapress. 
Kang, P. J. \& Nam, K. W.(2013). Notes on three marine algal species from Korea. Journal of Fisheries and Marine Sciences Education 25, 775 780.

Kang, P. J. \& Nam, K. W.(2014). Notes on marine algal species from Korea. Journal of Fisheries and Marine Sciences Education 26, 236 243.

Kim, H. S. - Boo, S. M. - Lee, I. K. \& Sohn, C. H.(2013). National List of Species of Korea $\ulcorner$ Marine Algae $\lrcorner$ Seoul: Jeonghaengsa.

Kützing, F. T.(1847). Diagnosen einiger neuen ausländischen Algenspecies, welche sich in der Sammlung des Herrn Kammerdirectors Klenze in Laubach befinden. Flora 30, 773-776.

Lee, I. K. \& Kang, J. W.(1986). A check list of marine algae in Korea. The Korean Journal of Phycology 1, 311 325.

Lee, Y. \& Kang, S. Y.(2002). A Catalogue of the Seaweeds in Korea. Jeju: Jeju National University Press.

Lee, Y.(2008). Marine Algae of Jeju. Seoul: Academy Publication.
Masuda, M. · Yamagishi, Y. • Chiang, Y. -M. • Lewmanomont, K. \& Xia, B. M.(1997). Overview of Hypnea (Rhodophyta, Hypneaceae). In: Taxonomy of Economic Seaweeds. (Abbott, I.A. Eds) Vol.6, La Jolla, California: California Sea Grant College System.

Silva, P. C. - Basson, P. W. \& Moe, R. L.(1996). Catalogue of the benthic marine algae of the Indian Ocean. University of California Publications in Botany 79, 1 1259.

Tseng, C. K.(1984). Common Seaweeds of China. Beijing: Science Press.

Xia, B. M. \& Wang, Y. Q.(1997). Some species of the genus Hypnea (Gigartinales, Rhodophyta) from China. In: Taxonomy of Economic Seaweeds. (Abbott, I.A. Ed) Vol. 6. La Jolla, California: California Sea Grant College System, 193 206.

- 논문접수일 : 2015년 01월 19일

- 심사완료일 : 1차 - 2015년 02월 03일

- 게재확정일 : 2015년 02월 04일 